\title{
The Making of Global Public Authorities: The Role of I I Is in Setting International Labor Standards
}

\author{
Yifeng Chen*
}

\begin{abstract}
Through liberal interpretations of their mandates, international financial institutions (IFIs) have been able to constantly redefine their own roles. The activities of IF Is have for a long time moved beyond purely financial matters. In seeking popular legitimacy, during the past decades, IF Is have embarked on a governance vocation and reinvented themselves as actors of global governance. In this way, If Is increasingly absorb Labor standards into their operational policies. The inclusion of Labor standards into the 2016 Environmental and Social Framework of the World Bank serves as a recent example. This chapter examines the role and limitations of IFIs in setting and enforcing Labor standards. Engagement with Labor issues also presents enormous knowledge management and institutional challenges to IF Is. This brings further cultural, ideological and institutional changes to IFIs. In conclusion, the potential of IFIs transforming into public authorities of global environmental and social justice deserves close scrutiny.
\end{abstract}

\section{Introduction}

The attitude of international financial institutions (IFIs) towards Labor protection in general was rather passive and at best ambivalent before the 2000 . Labor protection was not conceived as integral to the IFIs policies. The case of structural adjustment projects is a highly illustrative example, where the mplementation of privatization, marketization and deregulation has led to large scale lay-offs and deterioration of social protection, notoriously in the post-communist reforms of eastern European countries. Empirical studies have shown that the structural adjustment projects enforced by the IFIs in

* Associate Professor of International Law, Peking University Law School. Email: yifeng.chen@ pku.edu.cn. 
general have led to less protection of economic and social rights, particularly the worker' rights in borrowing countries. ${ }^{1}$

Such a passive approach has its constitutional and philosophical reasons. Constitutionally, most IFIs are barred by their constituent documents from intervening in domestic affairs of member states, and Labor issues are considered a domestic matter par excellence. When the World Bank adopted the comprehensive development framework and added a governance perspective to economic development in the 1990s, ${ }^{2}$ Labor protection was left out of the governance dimension on purpose. Labor issues were too domestic and too costly to interfere with. Philosophically, Labor was rendered as an element of production and measured in terms of cost and rigidity in traditional developmental economics. Many restructuring projects funded by IFIs compelled the recipient states to deregulate Labor markets so as to bolster economic development. Labor regulation does not easily fit with the neo-liberal economic doctrines of most IFIS.

However, the past two decades witnessed a changing attitude of IFIs and their growing engagement with Labor protection. The incorporation of Labor protection into the work of IFIs has been a fairly recent phenomenon. The change of position is largely a response to the growing external pressure wrought on IFIs. Public criticism against IFIs on the adverse social impact of their work intensified in the late 1980s. The neo-liberal prescriptions of IFIs met with questions from the borrowing countries and were increasingly challenged among scholars. The pressure from the trade unions in large shareholders, such as the American Federation of Labor-Congress of Industrial Organization (AFL-CIO), ${ }^{3}$ also plays an influential role in pressing for the policy changes of the World Bank and the International Monetary Fund (IMF).

1 See M. Rodwan Abouharb \& David Cingranelli, Human Rights and Structural Adjustment (Cambridge University Press 2007).

2 The Comprehensive Development Framework was advocated by the then World Bank President James Wolfensohn, referring to an inclusive, holistic approach to development that links the social, environmental, governance aspects of development to its economic and financial elements. See James Wolfensohn, "New Directions and New Partnerships, Address to the Board of Governors at the Annual Meetings of the World Bank and the International Monetary Fund (10 October 1995)" in World Bank, Voices for the World's Poor: Selected Speeches of the World Bank President James D. Wolfensohn, 1995-2005 (World Bank 2005), pp. 28-40.

3 The AFL-CIO has repeatedly requested the World Bank and IMF to commit to international Labor standards. See, for examples, AFL-CiO, "Executive Council Statement on Asian Financial Crisis" (29 January 1998) <https://aflcio.org/about/leadership/statements/asianfinancial-crisis> accessed 6 May 2018; AFL-CIO, "Executive Council Statement on Equitable, Democratic, Sustainable Development” (18 February 200o) <https://aflcio.org/about/leadership/statements/equitable-democratic-sustainable-development> accessed 6 May 2018. 
After the 2000s, Labor protection started to enter into the forefront of the work of IFIs.

The transformation of IFIs' Labor policy is largely facilitated and aided by the fundamental Labor rights movement advocated by the International Labour Organization (ILO). The ILO has experienced a bitter institutional transformation in a quest for relevance in the post-Cold War world order. ${ }^{4}$ Until the late 1990s, the ILO has successfully reinvigorated its international foothold by formulating and advocating a set of fundamental Labor rights, ${ }^{5}$ embodied in the Declaration on Fundamental Principles and Rights at Work adopted on 18 June 1998. The declaration, for the first time, formally pronounced a list of Labor rights characterized by fundamentals, i.e., freedom of association and collective bargaining, prohibition of forced Labor, prohibition of child Labor, and non-discrimination in respect of employment and occupation. ${ }^{6}$ Equally important, the 1998 Declaration pronounced that such fundamental Labor rights emanate from the fact of states being members of the ILO.

With the adoption of the 1998 Declaration and its follow-up, the ILO embarked upon fundamental Labor rights advocacy. This includes two strategies. One front is the campaign with the member states for universal ratification of ILO fundamental Labor conventions, by far a recognizable success if measured by the steady growth in the number of treaty ratifications. On the other front, the ILO initiated dialogues on the possible integration of Labor standards with IF Is whose work has a significant Labor ramification. ${ }^{7}$ A growing international recognition of fundamental Labor rights was observed in the late 199os and the

4 For a useful reference, see ILO, "Report of the Director-General, Defending Values, Promoting Change: Social Justice in a Globalized Economy: An ILo Agenda" (Geneva: International Labor Office 1994).

5 The notion of fundamental Labor rights is much debated in scholarship. For a critical appraisal, see Philip Alston, "Core Labor Standards' and the Transformation of the International Labor Rights Regime” (2004) 15 European Journal of International Law 457, pp. 457-521.

6 The core Labor rights enshrined in the Declaration are embodied in and endorsed by eight ILO fundamental conventions, chronologically, the Forced Labor Convention, adopted 28 June 1930 (No.29); the Freedom of Association and Protection of the Right to Organize Convention, adopted 9 July 1948 (No.87); the Right to Organize and Collective Bargaining Convention, adopted 1 July 1949 (No.98); the Equal Remuneration Convention, adopted 29 June 1951 (No.10o); the Abolition of Forced Labor Convention, adopted 25 June 1957 (No.105); the Discrimination (Employment and Occupation) Convention, adopted 25 June 1958 (No.111); the Minimum Age Convention, adopted 26 June 1973 (No.138); and the Worst Forms of Child Labor Convention, adopted 17 June 1999 (No.182).

7 The ILo tried to initiate with the institutional dialogue with the World Bank and the IMF as early as late 1980s. As part of its efforts, The ILO, in cooperation with other parts of the UN system and the Bretton Woods institutions, organized a High-level Meeting on Employment and Structural Adjustment in November 1987, yielding to no concrete result. 
beginning of the new millennium. The inter-agency cooperation between the ILO and IFIs, despite their continued difference of approaches to Labor, was further deepened after the 2008 economic crisis. ${ }^{8}$

The entry of Labor standards into the work of IFIs has important implications for Labor governance at global level and for the function and identity of IFIs as well. The incorporation of Labor standards into the policy documents of IFIs may contribute to the development of a set of autonomous IFI Labor standards. These standards are transnational in nature. Their enactment and enforcement are largely self-standing. They are useful supplements, as well as strong competitors, to the international Labor conventions and to the existing procedures and mechanisms of enforcement. They open new paths of global Labor governance. Meanwhile, increasing engagement with Labor protection and other social policy is also quietly transforming the philosophy, culture and structure of IF Is. In committing to environmental protection and social justice, the IFIs have moved away from their role of financial instrumentality and are reconfiguring themselves into public authorities of global governance. Such a reconceptualization brings new intellectual tools and normative frameworks to interpret and regulate the role of IF Is in global governance.

This chapter offers a comprehensive evaluation of the IFIs' engagement with Labor standards. It aims to examine the paths, mechanisms and limits of how IFIs may set and enforce Labor standards in a transnational context. It provides an overview of the history and status quo of IFIs' adoption of Labor standards in Section 2. The richness and diversity of approaches among IFIS are highlighted. Exploration of the substantive content of IFI Labor standards from a comparative perspective follows in Section 3. Controversies surrounding relevant Labor standards are discussed in detail. In Section 4, the relationship of the IFI Labor standards to the ILO standards is analyzed from a normative perspective, and is also reviewed in light of politics between the ILO and IFIs. Section 5 sketches out several challenges that IFIs face in incorporating Labor standards. The tension persists between an economic perspective and a rights-based approach to Labor. The chapter concludes, in Section 6 , with some philosophical reflections on the evolving role of IFIs in global governance.

8 The Summit of G2o at London in April 2009 requested the ILO to assess Labor impact of the actions taken and advise on further measures. See G2o Leaders' Statement, "The Global Plan for Recovery and Reform" (2 April 2009) <https://www.treasury.gov/resource-center/international/g7-g20/Documents/London\%2oApril\%202009\%2oLeaders\%2ofinal-communique .pdf> accessed 6 May 2018. 


\section{Labor Standards in Social Policies of IfIS: An Evolutionary Trajectory}

The incorporation of Labor protection into the work of IF Is is a fairly recent phenomenon. This was pioneered by a modest reference to the core Labor standards in the social protection strategy of the Asian Development Bank (ADB) in 2001. The ADB committed to ensure that its procurement of goods and services, contractors, subcontractors and consultants was in compliance with core labor standards. ${ }^{9}$ Taking that as a starting point, the ADB and ILO embarked upon various forms of cooperation thereafter, and the ILO was invited to provide assistance and advice to the work of $\mathrm{ADB}$, at both policy and project levels. ${ }^{10}$ Yet, the actual impact of Labor policy on the work of the ADB should not be overstated. Not only the actual enforcement of Labor rights across the ADB projects remains limited and soft, but also the Labor protection in the $\mathrm{ADB}$ is confined to a passive Labor policy to promote the operational efficiency of Labor markets.

A full recognition of Labor standards had to wait until the adoption of the Performance Standards on Social \& Environmental Sustainability by the International Finance Corporation (IFC) in 2006.11 Labor and working conditions are featured as a self-standing performance standard. This was the first time a significant IFI had given its full endorsement to the Labor standards in an operational policy. The IFC Labor standards are characterized by the following features, inter alia: an express reference to the ILo fundamental Labor conventions, a comprehensive recognition of all core Labor rights, a due emphasis on the occupational health, and an extended protection to contracted workers and workers in supply chains. The IFC Labor standards were further elaborated in the revised Performance Standards of 2012. ${ }^{12}$

9 АDв, "Social Protection Strategy" (2001) <https://www.adb.org/sites/default/files/ institutional-document/3210o/social-protection.pdf $>$ accessed 6 May 2018, pp. 15-6.

10 A comprehensive cooperation agreement was signed between the ILO and ADB. In addition, the ILO and ADB also agree on reciprocal representations on each other's annual meeting, as well as a regular senior consultation meeting on a yearly basis. See Memorandum of Understanding between the Asian Development Bank and the International Labour Organization (9 May 2002) <https://www.adb.org/sites/default/files/institutional-document/33511/files/mou-ilo.pdf $>$ accessed 6 May 2018.

11 IFC, "Performance Standards on Social \& Environmental Sustainability" (30 April 2006) <https://www.ifc.org/wps/wcm/connect/6o8f3a804942f69aaa86fe4f5ddda76e/SustainabilityPolicy.pdf?MOD=AJPERES $>$ accessed 6 May 2018.

12 IFC, "Performance Standards on Social \& Environmental Sustainability" (1 January 2012) <https://www.ifc.org/wps/wcm/connect/115482804a0255db96fbffd1a5d13d27/PS_ English_2012_Full-Document.pdf?MOD=AJPERES $>$ accessed 6 May 2018. 
The successful incorporation of Labor standards by the IFC is largely attributable to the fact that the IFC engages exclusively in private sectors. Those potential clients who gain access to the IFC are usually those economically better-off, administratively well-organized companies. These IFC policy requirements are often in alignment with existing corporate policies on social responsibility and their implementation does not raise insurmountable difficulties from the perspective of a company. Moreover, in essence the Labor policy of the IFC usually goes little beyond requiring the companies to comply with the existing national laws where they operate. The scenario would get much more complicated when an IFI which engages principally in public lending tries to extend its policy to Labor issues.

The example set by the IFC was quickly followed by the European Bank for Reconstruction and Development (EBRD) in 2008 and the European Investment Bank (ЕІВ) in 2009. ${ }^{13}$ The EBRD adopted its first environmental policy in $1991 .{ }^{14} \mathrm{~A}$ renewed version of the Environmental and Social Policy was adopted in 2008 where Labor and working conditions were inserted as a separate standard. ${ }^{15}$ The EBRD acknowledges its due diligence obligation not to finance projects in contravention of the host country's international legal obligations on environmental protection and human rights. In the 2008 policy, the EBRD emphasized the importance of respect for the freedom of association and right to collective bargaining, which was non-existent in its previous policy statement. Like the IFC, it fully endorses all ILO core Labor standards. Notably the EBRD also paid heed to the law and practice of the European Union on nondiscrimination and retrenchment.

The EIB adopted in 2009 the Environmental and Social Principles and Standards and expressly acknowledged the ILO core Labor standards. ${ }^{16}$ The ЕІв policy applies to both public sector and private sector, albeit that the ensuing obligations of clients in different sectors do differ in nature. ${ }^{17}$ In its 2013 Environmental and Social Handbook, the EIB further extended its recognition to

13 The EBRD expressly acknowledged that its policy review is partly driven by the adoption of performance standards by the IFC in 2006. See EBRD, "Sustainability Report" (2008), p. 42.

14 It is to be noticed that in the previous version of Environmental Policy of 2003, the EBRD had already addressed "worker protection issues" including occupational health and safety, harmful child Labor, forced Labor and discriminatory practices. See EBRD, "Environmental Policy" (2003) <http://www.ebrd.com/downloads/research/policies/policy. pdf $>$ accessed 6 May 2018.

15 EBRD, "Environmental and Social Policy" (12 November 2008) <http://ebrd.com/ downloads/research/policies/2008policy.pdf> accessed 6 May 2018.

16 EIB, Environmental and Social Handbook (2013), pp. 18-19.

17 Ibid, p. 15 . 
the UN Guiding Principles on Business and Human Rights. ${ }^{18}$ Another feature of the ЕІв policy is its emphatic protection for migrant workers to whom employers are required to accord fair and non-discriminatory treatment. ${ }^{19}$ Moreover, the ЕІв also instituted an independent Labor audit system. Where the EIB considers the project as involving a high risk of Labor violations or such wrongful activities having occurred, the ЕІв may require its borrowing clients to carry out a Labor audit by commissioning an independent third party. ${ }^{20} \mathrm{As}$ the EIB has constantly sought to align itself with the policies of the European Union on sustainability and accountability, its Labor and social policy is broad and proactive.

The precedents set by the IFC, the EBRD and the EIB were inspiring and encouraged other IFIs. Since then, there is a growing acceptance of Labor standards among IFIs. Of course, many other IFIs have refrained from instituting a Labor policy so far, the International Monetary Fund (IMF) and the International Fund of Agricultural Development (IFAD) being prominent examples.

For those IFIs that incorporate Labor standards, there are roughly two categories. In some cases, a comprehensive framework for Labor protection has been pursued. For example, in 2013 the African Development Bank (AfDB) Group ${ }^{21}$ adopted its Integrated Safeguards System. ${ }^{22}$ Its policy on Labor protection is also comprehensive and is close to that of the IFC and of the EBRD. Another high profile case was the adoption by the World Bank of its Environmental and Social Framework in 2016 after several years' of consultation and debates. In those cases, Labor protection is developed as an elaborate, selfstanding standard. Substantive Labor rights, coverage of workers, management of Labor relations and grievance mechanisms are established.

In some other cases, a succinct version of an environmental and social policy is enacted with a brief reference to Labor standards. The examples could include the Sustainability Policy of the Nordic Investment Bank (NIB) adopted on 1 September 2011, where the NIB required its clients to respect

\footnotetext{
$18 \quad$ Ibid, p. 7 o.

$19 \quad$ Ibid, p. 73.

$20 \quad$ Ibid, p. 76.

21 The African Development Bank Group includes African Development Bank (AfDB) and African Development Fund (AfDF).

22 African Development Bank Group, "Integrated Safeguards System: Policy Statement and Operational Safeguards" (2013) <https://www.afdb.org/fileadmin/uploads/afdb/ Documents/Policy-Documents/December_2013_-_AfDB\%E2\%80\%99S_Integrated_ Safeguards_System___Policy_Statement_and_Operational_Safeguards.pdf> accessed 6 May 2018.
} 
the four core Labor rights and to provide for safe and healthy working conditions. ${ }^{23}$ The Black Sea Trade and Development Bank (вSTDв) also upgraded its Environmental and Social Policy in 2013 and openly committed to "respect for human rights in a working environment," as embodied in the ILO core Labor standards. ${ }^{24}$ In 2016 the New Development Bank (NDB) adopted its Environmental and Social Framework which sets occupational health and safety at the center of Labor protection. ${ }^{25}$ And in the same year, the Asian Infrastructure Investment Bank (AIIB) approved its Environmental and Social Framework and prescribed Labor standards for both public and private sectors. In addition, projects involving use of forced Labor or child Labor are expressly listed on AIIB's list of exclusions from financing. ${ }^{26}$

The heterogeneity and richness of IFIs in their approaches to Labor protection are to be emphasized. Firstly, the level of Labor protection is uneven between different IFIs. While some IFIs are capable of enforcing a comprehensive framework of Labor standards, some afford only a limited scheme of protection. Some limit applicable Labor standards to the four core Labor standards plus safe working conditions, and some also cover other categories of Labor standards such as wages and rest, migrant workers, and others. Some institutions extend protection from direct workers to contracted workers and supply chain workers, yet many others limit their protection to workers directly engaged by borrowers.

Secondly, the mechanisms of enforcement are diverse. Labor standards could be enforced through a variety of means and procedures, including prior plans or commitments of the borrower, a project's on-site grievance mechanism, independent Labor inspection, or an IFI's complaint mechanism. In some cases, projects or clients engaging in serious Labor violations are listed as exclusions from eligibility for financing.

Thirdly, institutionalization of Labor standards within IFIs varies in terms of degree and means. The majority consider Labor protection as an essential

23 NIB, "Sustainability Policies and Guidelines" (21 March 2012) < https://www.nib.int/ filebank/56-Sustainability_Policy_Guidelines-2012.pdf> accessed 6 May 2018.

24 See вSTDв, "Environmental and Social Policy" (1 January 2014) <https://www.bstdb.org/ about-us/how-we-operate/Environmental_and_Social_Policy.pdf $>$ accessed 6 May 2018.

25 NDB, "Environmental and Social Framework" (11 March 2016) <https://www.ndb.int/wpcontent/themes/ndb/pdf/ndb-environment-social-framework-20160330.pdf $>$ accessed 6 May 2018.

26 AIIB, "Environmental and Social Framework" (February 2016) <https://www.aiib.org/ en/policies-strategies/_download/environment-framework/20160226043633542.pdf>accessed 6 May 2018. 
element of sustainability, ${ }^{27}$ while some takes a no-harm approach and Labor matters are treated in their safeguards policies, ${ }^{28}$ and still others have lifted Labor protection up to one of their institutional core values as in the case of the World Bank. ${ }^{29}$ The difference of approaches is not just a matter of institutional willingness or awareness of Labor protection but may also reflect varying institutional philosophies on Labor.

In the course of gradual absorption of Labor standards by IFIs, the ILO has played an indispensable role in the dissemination of knowledge and expertise about Labor standards. For example, the ADB has engaged in close cooperation with the ILO. A testimony to such cooperation was the joint publication of a handbook on core Labor standards in $2006 .{ }^{30}$ The EBRD also actively resorted to the ILO expertise when designing its Labor standards. In 2006, a thematic meeting on Labor issue was hosted by the ILO where the EBRD staff met with representatives from trade unions, employers and ILO experts. ${ }^{31}$ Another prominent example can be found in the formulation of the Environmental and Social Framework of the World Bank. The World Bank has organized three Labor expert meetings respectively in Jakarta (2013), London (2015) and Washington (2015). ${ }^{32}$ In all meetings, the ILO representatives were present.

Inter-agency learning is an important factor accounting for the spread of Labor standards. The Multilateral Finance Institutions Working Group on Environment (MFI-WGE) was initiated in 199os and serves as a useful platform for senior managers of IFIs to discuss and coordinate policies towards

27 The EBRD is a good example in this regard. See EBRD, "Environmental and Social Policy" (12 November 2008).

28 This is the case of the African Development Bank Group's Integrated Safeguards System.

29 World Bank, "Review and Update of the World Bank's Safeguard Policies: The Proposed Environmental and Social Framework, Background Paper" (2 September 2014), p. 1.

30 ADв \& ILO, Core Labor Standards Handbook (Manila 2006).

31 See EBRD, "Sustainability Report" (2006), p. 11.

32 See World Bank, "World Bank's Safeguard Policies Review and Update, Expert Focus Group on the Emerging Area, Labor and Occupational Health and Safety" (Indonesia 23 March 2013) <https://consultations.worldbank.org/Data/hub/files/meetings/Safeguards_ Focus_Group_Labor_Indonesia_Summary_Final.pdf > assessed 6 May 2018; World Bank, "World Bank's Safeguard Policies Review and Update, Labor expert group" (London 21 January 2015) <https://consultations.worldbank.org/Data/hub/files/consultation-template/ review-and-update-world-bank-safeguard-policies/en/meetings/safeguards_london_ focus_group_meeting_jan_21.pdf> assessed 6 May 2018; World Bank, "Meeting of Labor Experts on the Second Draft of the World Bank's Environmental and Social Standard 2: Labor and Working Conditions (ESS 2)" (Washington DC 18 September 2015) <https:// consultations.worldbank.org/Data/hub/files/consultation-template/review-and-updateworld-bank-safeguard-policies/en/meetings/ess2_meeting_report_o915.pdf> assessed 6 May 2018. 
environmental and social issues. As increasingly social issues are included in the safeguards policy, this working group has been recently renamed as Multilateral Finance Institutions Working Group on Environmental and Social Standards (MFI-WGESS). This working group is rather informal but has been instrumental for institutional learning on environmental and social standards. For example, the African Development Bank expressly acknowledged that its earlier drafts of safeguards policies "have been reviewed by the IFC, World Bank, Asian Development Bank and other members of the MFI Working Group on the Environment (MFI-WGE)." "T3 The World Bank also expressly acknowledged that its Labor standards are "derived from provisions of other MDBs." 34

The Rise of Transnational Labor Standards of IF Is: Content and Controversies

As the engagement with Labor standards by IFIs grows, there emerges a recognizable body of Labor standards that are formulated, applied and enforced in a transnational context. While Labor standards are traditionally considered a rather state-centered matter, clearly states are no longer the only loci where Labor standards are debated and enacted, nor are states the only actors. ${ }^{35} \mathrm{On}$ the contrary, Labor standards are increasingly visible in free trade agreements, investment arrangements and in the policy documents of the IFIs. Such a body of Labor standards is prominently transnational by nature. Not only does its formulation occur outside states, so too does its enforcement. Exactly by recognizing and enforcing Labor standards in a transnational space, the IF Is play an increasingly relevant and appreciated role.

The IFI Labor standards are formulated in policy documents of IFIs, usually approved by the boards of executive directors. As an institutional policy and internal regulation, they address primarily the staff of IFIs. The IFI Labor standards do not automatically bind the member states or companies. Strictly speaking, the application of the IFI Labor standards is project-specific. The scope of application is not based upon the principle of personam jurisdiction, but instead upon the principle of in rem jurisdiction. The Labor standards can

33 See the statement in the "Acknowledgement of the African Development Bank Group, Integrated Safeguards System: Policy Statement and Operational Safeguards" (2013).

34 World Bank, "World Bank Safeguard Policies Review and Update, Proposed Environmental and Social Framework: Background Paper" (2 September 2014), p. 11.

35 The same is true with the ILO. The role of the ILO in formulating hard international Labor standards is declining in recent years. 
only be extended to its borrowers through, and to the extent of, project loans and grants.

The choice of the term "transnational" is a purposeful decision here to highlight the operational feature of the IFI Labor standards. ${ }^{36}$ The IFI Labor standards do not belong to the formal corpus of international Labor standards, a term traditionally associated with ILO conventions and recommendations. The IFI Labor standards are not "international" in origin. In a project-specific manner, the IFI Labor standards are transmitted to and enforced by borrowers, be they public or private. Through project loans, a transnational space is constructed and maintained, and various actors and norms interact within the space with the IFI sitting at the center. Such a transnational space is built upon the capabilies and resources of the IFIs. And the IFI Labor standards are part of the normative edifice of the transitional space.

\subsection{Content of IFI Labor Standards}

The body of IFI Labor standards is not monolithic, but rather amorphous. It is not a single set of uniform Labor standards, but an aggregation of various sets of independent Labor standards practiced by different IFIs. To group all those standards under the label of IFI Labor standards risks reduction and oversimplification of the richness, diversity and nuance of the IFIs in practicing Labor standards. Some IFIs have incorporated a comprehensive scheme of Labor standards, equal to a mini Labor code. ${ }^{37}$ Some may just include general principles in their policy documents. ${ }^{38}$

Yet, a comparative survey shows that a hard core of IFI Labor standards does exist, which is comprised of the ILo fundamental Labor rights, also called core Labor standards. Freedom of association and collective bargaining, prohibition of forced Labor, prohibition of child Labor and non-discrimination are solidly established as the foundation of the IFI Labor standards. However, even as the core Labor standards are widely accepted, their exact contents are in no way uniform or identical. The levels of commitment and strengths of enforcement hinge upon every institution's own philosophy, tradition and capacity.

Another essential aspect of the IFI Labor standards involves safe working conditions. This is the least politically sensitive and morally uncontested part of Labor standards. It is among the first cluster of Labor standards received by

$36 \quad$ For a genealogical account on the use of the concept in the literature of international law and international relations, see Christer Jönsson, "Capturing the Transnational: A Conceptual History" in Jonas Tallberg \& Christer Jönsson (eds), Democracy Beyond the Nation State? Transnational Actors and Global Governance (Palgrave Macmillan 2010), pp. 22-44.

37 See for example the World Bank and the EBRD.

38 See for the examples of NIB, NDB and AIIB. 
the IFIs. Occupational health and safety was already mentioned in the EBRD Environmental Policy of 2003. ${ }^{39}$ The World Bank's relevant standards have their origin in its early Environmental Health and Safety Guidelines (EHSG). The World Bank's current standards on occupational health and safety are extensive. They require, among others things, identification of potential hazards, preventive and protective measures, preparedness and responses to emergency and effective remedies for occupational injuries, deaths, disability and disease. The right of workers to refuse to work in hazardous working environments is also reaffirmed in the World Bank Environmental and Social Framework. ${ }^{40}$

Of course, core Labor standards and safe working conditions are not exclusive items of recognized IFI Labor standards. Other standards may involve workers' rights related to hours of work, wages, overtime, compensation and benefits, ${ }^{41}$ social security, ${ }^{42}$ and the protection of migrant workers. ${ }^{43}$ The IF Is enjoy considerable discretions to elaborate their own policy preferences and priorities.

\subsection{The Reach of IFI Labor Standards: Applicable Scope}

To whom are the IFI Labor standards to be applied? What is the scope of protected workers? What are possible jurisdictional linkages? What is the criterion to set the borderline of the IFI Labor standards? A determination on the applicable scope often involves considerations of economic, legal and political factors.

The jurisdictional linkage for the IFIs is financing projects, involving IFI resources. Then the question is whether all persons working on the project or for the project are subject to protection. It is indisputable that those workers the borrowers or clients directly contracted for the implementation of the project are subject to the protection of IFI Labor standards. These workers are called "direct workers." This reflects typically a perspective that treats the borrowers as actual employers and the legal linkage could be established on the basis of employment contracts. Yet, this usually consists of only a small portion of the total Labor force that works on a project. In the first draft of its Environmental and Social Framework, the World Bank limited the applicability of Labor standards to those project workers directly employed by the borrowers. This received critical comments from workers' organization as this formalistic

39 See EBRD, "Environmental Policy" (2003), p. 3, footnote 1.

40 World Bank, "Environmental and Social Framework" (2016), pp. 57-58.

$41 \quad$ Ibid, p. 54.

42 See EBRD, "Environmental and Social Policy" (2008), p. 23.

43 See EIB, Environmental and Social Handbook (2013), p. 70. 
approach would confine the protection of workers to an extremely limited scope. ${ }^{44}$ It is a legitimate concern that the responsibility of a borrower could be easily circumvented through outsourcing and by use of agency workers.

Very often, many workers working on the project are engaged by a third party to perform certain functions for the project, known as "contracted workers." Many IF Is expressly extend their Labor standards to the protection of contracted workers. These workers are not directly contracted as employees of the borrowers. Nevertheless a jurisdictional linkage might be established on the basis that their work effectively contributes to the implementation of the project. Such a contribution test sometimes risks an unwarranted expansion of the applicable scope to an undesirable extent. Theoretically, a project may involve thousands of contracts with third parties for procurement of different services. This is the logic of division of Labor and specialization in modern society. Obviously, not all workers, even those who might come to perform services on site, can be necessarily qualified as contracted workers. Then the question arises where the line is to be drawn to distinguish those workers subject to protection and those that are not.

It seems that the test of "core functions" has been widely accepted. The EBRD has limited the scope of contacted workers to those who "performs work directly related to the core functions of the project." 45 An identical definition has been used by the World Bank. ${ }^{46}$ The IFC employs the term "core business processes," and yet its actual meaning is the same as "core functions" in practice. As the World Bank provides, "core functions' of a project constitute those production and/or service processes essential for a specific project activity without which the project cannot continue."47 This means that only those workers who are essential to the operation of a business or a project are qualified as contracted workers. And the responsibility of the borrowers to Labor protection would not extend to an unknown boundary. In practice, what are the core functions and who are serving the core function remains a highly debatable question. However, efforts seem to be invested towards achieving a reasonable and balanced approach.

As for the contracted workers, they would normally enjoy the same level of protection as offered to direct workers. Moreover, additional efforts may be

44 ITUC/Global Unions, "Major Weaknesses in World Bank's Draft Labor Standards Safeguards" (22 July 2014), p. 4; "French Non-paper on the Bank's Safeguards Review” (April 2015); "German Comments on the World Bank Safeguards Review" (April 2015); "United States Comments on World Bank Safeguards Review - Phase 2" (26 March 2015).

45 EBRD, "Environmental and Social Policy" (2008), p. 25.

46 World Bank, "Environmental and Social Framework" (2016), p. 52.

47 Ibid. 
demanded from borrowers. This could include, for example, making reasonable efforts in choosing legitimate and reliable third parties, monitoring third parties' performances in Labor protection and ensuring the availability of grievance mechanism for contracted workers. ${ }^{48}$

Probably the most controversial case is whether the Labor standards should reach to the "workers of supply chains." To address the Labor situation in supply chains is largely borrowed from the model of corporate social responsibility. The linkage for IFI Labor standards could only be explained by measuring the market influence the IFIs and their borrowers are capable of exercising as a business partner. It was the IFC which for the first time requested its clients to address Labor situations in supply chains in its performance standards of 2006. The IFC limited the responsibility of its clients to inquiring of its suppliers of Labor-intensive industries about child Labor and forced Labor. ${ }^{49}$ The same provision was followed by the EBRD in 2008. Then in 2012, the IFC extended its regulation of supply chain workers to cover workplace safety. Meanwhile, a limitation was added to cover primary supply chains only. ${ }^{50}$ The obligation of the borrowers in dealing with the Labor abuse of the supply chain is comparatively soft. It is widely acknowledged that "the ability of the client to fully address these risks will depend upon the client's level of management control or influence over its primary suppliers." ${ }^{51}$ Therefore, the borrowers may require the primary supplier to take appropriate steps to remedy child Labor, forced Labor, or unsafe working conditions, or, in case of need, switch business to responsible suppliers.

The subjection of the supply chain to the IFI Labor standards may have its rationale for the private sector, as it could take advantage of the corporate social responsibility model. Yet it is highly questionable whether it is appropriate or feasible to mechanically transpose the system to sovereign lending. Firstly, in the case of sovereign loans it is essential to stress the sovereign nature of the borrowers in terms of responsibility to Labor protection. It is neither desirable nor productive to reduce the sovereign nature of the borrowers to their market role. The borrowers may address child Labor, forced Labor and safe working conditions through legislative, administrative and judicial means. From the perspective of a sovereign, domestic suppliers are of no difference to other legal subjects who are obliged to abide by relevant domestic laws. Secondly, in

48 See World Bank, "Environmental and Social Framework" (2016), p. 58; also IFC, "Performance Standards on Social \& Environmental Sustainability" (2012), p. 5.

49 See IFC, "Performance Standards on Social \& Environmental Sustainability" (2006), p. 10.

50 See IFC, "Performance Standards on Social \& Environmental Sustainability" (2012), p. 6.

51 Ibid. An almost identical expression can be found in the World Bank, "Environmental and Social Framework" (2016), p. 60. 
relation to workers of supply chains, the IFI Labor standards normally impose upon the borrowers with relatively soft obligations, such as due diligences, inquiry, and switching to new suppliers in case of persistent violations. Those provisions completely ignore the sovereign nature of the borrowers. In cases of child Labor and forced Labor, a responsible sovereign should prosecute the suppliers according to its national laws, and not substitute its legal duties with business decisions. Therefore, the current regime as it stands may function to weaken the protection for workers rather than strengthen it. Last but not least, as pointed out by China and India during the consultation on the World Bank's Environmental and Social Framework, many suppliers are from abroad and it is extremely difficult for the borrowers to monitor the actual Labor conditions of foreign suppliers. ${ }^{52}$

Sovereign states and private sector corporations as clients of the IFIs are fundamentally different in some regards. To apply a corporate social responsibility model to public lending could be counter-productive to Labor protection. The application of Labor standards to workers of supply chains in the public sector would require reconsideration.

\subsection{Politics of Labor Standards: The Freedom of Association as an Example}

Even though the core Labor standards receive broad endorsement, their substance and actual enforcement exhibit profound differences in practice. For example, it is noticed that different countries have very different approaches to the workers' right of unionization. There were, and probably still are, hesitations among the IFIs to include the freedom of association and collective bargaining, which is considered a highly political and sensitive issue in borrowing countries. Even for those rights of a seemingly less political nature,

52 The opinion of the Chinese government is expressed in a World Bank consultation meeting in China, see "Review and Update of the World Bank's Environmental and Social Safeguard Policies, Phase 3, Feedback Summary: Consultative Meeting with Provincial Governments" (Kunming 29 October 2015) <https://consultations.worldbank.org/Data/ hub/files/consultation-template/review-and-update-world-bank-safeguard-policies/en/ meetings/final_feedback_summary_for_phase_3_consultation_with_chinese_provincial_ governments_and_pmos_in_yunnan_october_29.pdf> assessed 6 May 2018. The position of the Indian government can be found at the "Review and Update of the World Bank's Environmental and Social Safeguard Policies," Phase 3, Feedback Summary: Consultative Meeting with Indian Governmental Officials (New Delhi 5-6 November 2015) <http:// consultations.worldbank.org/Data/hub/files/consultation-template/review-and-updateworld-bank-safeguard-policies/en/meetings/final_feedback_summary_for_phase_3_ consultation_with_indian_ministries_state_governments_and_pias_november_5-6.pdf> assessed 6 May 2018. 
such as the prohibition of child Labor, the matter may also be received with divergent attitudes in different cultures.

The freedom of association is probably the most politically sensitive right of workers. For many countries, the freedom of association lies at the heart of Labor protection. And the freedom of association is deeply embedded in a liberal political tradition. Labor protection through institutionalized unionization of Labor has functioned in a highly effective manner in countries like Sweden and Finland. ${ }^{53}$ Yet, in some other countries, the right to organize is not purely a matter of Labor protection and its exercise is restricted by law or in practice. ${ }^{54}$ This may include prior approval or registration for the formation of trade unions, and other forms of restrictions. The difference of positions towards the right to organize among states is also demonstrated by the fact that a number of countries have not ratified the Freedom of Association and Protection of the Right to Organize Convention (No. 87) or the Right to Organize and Collective Bargaining Convention (No. 98). Out of the eight ILO fundamental conventions, both conventions have received the least number of ratifications. ${ }^{55}$

The initial attitude of IFIs towards the freedom of association has also been very cautious. The Labor rights tackled by IF Is used to have a limited spectrum with a special focus on safe working conditions and prohibition of child or forced Labor. An explicit reference to freedom of association was often absent. As observed by Francis Maupin, the former legal counsel of the ILO, "freedom of association and collective bargaining continue to be regarded as civil rights which [World] Bank activities might facilitate, but it still believes that it is not in its mandate to actively promote them, and even less so where they might interfere with economic performance. ${ }^{56}$ This is partly due to the economic

53 See for example Reinhold Fahlbeck \& Bernard Johann Mulder, Labor and Employment Law in Sweden (Juristförlaget 2009), pp. 16-18.

54 See the observations of the ILO in its global report on the freedom of association, in ILO, "Freedom of Association in Practice: Lessons Learned, Global Report under the follow-up to the ILO Declaration on Fundamental Principles and Rights at Work" (International Labor Conference, 97th Session, 2008), p. 11.

55 By the end of March 2018, 154 countries have ratified the ILO Convention No.87, see <http://ilo.org/dyn/normlex/en/f?p=NORMLEXPUB:1130o:o::NO:11300:P11300_ INSTRUMENT_ID:312232:NO> assessed 6 May 2018, and 165 countries have ratified ILO Convention No.98, <http://ilo.org/dyn/normlex/en/f?p=NORMLEXPUB:1130o:0::NO:1130 o:P1130o_INSTRUMENT_ID:312243:NO> assessed 6 May 2018. These numbers are much lower than other 6 ILo fundamental conventions. In Contrast, the Worst Forms of Child Labor Convention (No.182) has received 181 ratifications by far.

56 Francis Maupain, The Future of the International Labour Organization in the Global Economy (Hart Publishing 2013), p. 78. 
perspective of seeing trade unions negatively as free riders. ${ }^{57}$ Moreover, many developing countries where the IFIs operate hold a conservative position towards freedom of association, and those IFIs engaging with public sectors are barred from interfering into the political affairs of the borrowing sovereigns. This was still the case when the World Bank proposed its first draft of Environmental and Social Framework in 2014. In its standard on Labor and working conditions, the World Bank refrained from mentioning the freedom of association among its objectives. Instead, the World Bank took a deferential attitude to the borrowing country. It expressly limited its support to the freedom of association only if the national laws of the borrowing country recognize it. ${ }^{58}$

This cautious approach of the World Bank met with fierce criticisms from Labor NGOs and experts, the ILO and developed countries. ${ }^{59}$ The main arguments are summarized as follows. First of all, all core Labor standards are indivisible and as a whole they constitute the floor of protection for workers. There is no reason to segregate the freedom of association from other standards. Secondly, freedom of association and collective bargaining are political rights by nature, and so are other core Labor standards. Freedom of association cannot be justifiably excluded on the grounds of its political nature. Thirdly, the silence of the World Bank might be construed to be permissive of suppressive or retaliatory measures against workers seeking to exercise freedom of association. ${ }^{60}$ Fourthly, the obligation to promote core Labor standards arises from states' membership in the ILO. ${ }^{61}$ As such, neither the World Bank nor the states should refuse to implement freedom of association on the basis of national laws. ${ }^{62}$

57 It used to be the mainstream opinion of the World Bank, see Hannah Murphy, "The World Bank and Core Labor Standards: Between Flexibility and Regulation" (2014) 21 Review of International Political Economy 399, p.405, p.417.

58 World Bank, "Environmental and Social Framework: Setting Standards for Sustainable Development, First Draft for Consultation" (30 July 2014) <https://consultations.worldbank .org/Data/hub/files/consultation-template/review-and-update-world-bank-safeguardpolicies/en/phases/first_draft_framework_july_30_2014.pdf> assessed 6 May 2018, pp. $36-37$.

59 See World Bank, "Safeguard Policies' Review Consultations: Nordic Baltic Position as of February 23, 2015" <http://consultations.worldbank.org/Data/hub/files/nordic_baltic_ comments_of_27_feb_2015.pdf> assessed 6 May 2018.

6o ITUC/Global Unions, "Major Weaknesses in World Bank's Draft Labor Standards Safeguards" (22 July 2014), pp. 2-3.

61 ILO, "Declaration on Fundamental Principles and Rights at Work and its Follow-up," adopted by the International Labor Conference at its Eighty-sixth Session (Geneva 18 June 1998).

62 ITUC/Global Unions, "Major Weaknesses in World Bank's Draft Labor Standards Safeguards" (22 July 2014), pp. 2-3. 
The World Bank quickly yielded to this pressure after a first round of consultation. The Bank switched to the opposite position in the second draft of the Environmental and Social Framework and provided an unqualified support to the freedom of association as part of its Labor policy. Such a radical change of position generated much concern among developing countries. The primary concern was the absolute nature of the World Bank statement. It is suggested by countries like China that the exercise of freedom of association and collective bargaining should be in accordance with national laws of borrowing countries. ${ }^{63}$ Some also suggest that the arrangement concerning the freedom of association and collective bargaining should be specified so as not to cause frustration to project implementation. ${ }^{64}$ In response, the World Bank decided to qualify its "support to principles of freedom of association and collective bargaining of project workers in a manner consistent with national law."65 This formula entered the final text of the World Bank's Environmental and Social Policy in 2016.66

\subsection{Feasibility of an Alternative Mechanism}

A highly relevant issue is concerned with the permissibility of the so called "alternative mechanism." To put it simply, in cases where the national laws of the borrowing countries arbitrarily prohibits or restricts the freedom of association, should workers be allowed to develop other means of solidarity as a remedy? In its second draft, the World Bank openly recognized the feasibility, as well as the lawfulness, of the alternative mechanisms autonomously

63 For the opinions of China, see "Review and Update of the World Bank's Environmental and Social Safeguard Policies, Phase 3, Feedback Summary: Consultative Meeting with Provincial Governments" (Kunming 29 October 2015) < https://consultations.worldbank .org/Data/hub/files/consultation-template/review-and-update-world-bank-safeguardpolicies/en/meetings/final_feedback_summary_for_phase_3_consultation_with_ chinese_provincial_governments_and_pmos_in_yunnan_october_29.pdf $>$ assessed 6 May 2018.

64 World Bank, "Comments/Observations of the Government of Bangladesh on the World Bank's Environmental and Social Safeguard Framework and other Related Documents" (January 2016), <http://consultations.worldbank.org/Data/hub/files/comments_from_ govt_of_bangladesh_on_essf-01_12_15.pdf> assessed 6 May 2018, p. 4.

65 World Bank, "Summary of Phase 3 Consultations and Bank Management Responses," p. 22.

66 The qualification of "in a manner consistent with national law" was harshly criticized by the ILO for the reason that a formula as such "undercuts the universal principles adhered to by the ILO's 187 member states and jeopardizes the purpose of having such an objective." See ILO, "Statement on the World Bank Environmental and Social Policy" (8 August 2016) <http://www.ilo.org/global/about-the-ilo/newsroom/statements-and-speeches/ WCMS_508328/lang--en/index.htm> assessed 6 May 2018. 
developed by workers. "Where national law restricts workers' organizations, the project will not restrict workers from developing alternative mechanisms to express their grievances and protect their rights regarding working conditions and terms of employment." ${ }^{67}$ The final text of 2016 further imposed an obligation of non-retaliation on the borrowing country. "The Borrower will not discriminate or retaliate against project workers who participate, or seek to participate, in such workers' organizations and collective bargaining or alternative mechanisms." 68

The meaning of the term "alternative mechanism" mentioned above is rather obscure and elusive. The World Bank offers no indication as to what possible remedial measures it actually refers to. Judging from the content, this paragraph is almost identical to the relevant words in the Labor standards of the IFC and most likely was transplanted from there. The IFC's explanations in its guidance notes shed some light on the alternative mechanism. Two scenarios are conceived. In the case of an absolute prohibition of forming trade unions, the clients of the IFC are requested to give formal recognition to worker committees and have dialogue with the workers' representatives. Or alternatively, when in some cases the national laws are silent on the matter, the clients are encouraged to give recognition to workers' organizations and engage collective bargaining with them. ${ }^{69}$ In other words, the alternative mechanism in the Labor standards of the IFC requires no more than a private recognition and enforcement of relevant Labor standards to the extent that is permissible under national laws.

However, to transpose the notion of an alternative mechanism from the IFC which engages exclusively with the private sector, to the World Bank which, to the contrary, deals exclusively with sovereign loans could be profoundly misleading and bring frustration. The clients of the World Bank are sovereign states. By requiring borrowing countries not to "seek to influence or control these alternative mechanisms," and not to retaliate against the workers who participated in workers' organization, the World Bank mistakenly mixes the states' role as public institutions with private employers. In other words, the World Bank is asking the borrowing countries to give exemption to the workers

67 Moreover, "the Borrower should not seek to influence or control these alternative mechanisms." World Bank, "Environmental and Social Framework" (2016), p. 53.

68 Ibid, p. 55 .

$69 \quad$ IFC, "Guidance Notes: Performance Standards on Social \& Environmental Sustainability" (31 July 2007) <http://www.ifc.org/wps/wcm/connect/topics_ext_content/ ifc_external_corporate_site/ifc+sustainability/our+approach/risk+management/ performance+standards/environmental+and+social+performance+standards+and+guid ance+notes $>$ assessed 6 May 2018, pp. 41-42. 
who might have breached domestic laws by organizing or participating in the workers' organization.

The inclusion of the alternative mechanism received critical repercussions from developing countries. For example, Chinese officials were of the opinion that the alternative mechanism "will be considered only where the national law allows such mechanism."70 Bangladesh and others were very much concerned about undesirable conflict with the World Bank standards and national laws if the alternative mechanism were to be put into practice. ${ }^{71}$

The key to the debate is whether the alternative mechanism is within or outside of the ambit of national law.

The World Bank has yet to define the precise concept of alternative mechanism for its own Labor policy. It is, however, very clear that, if the World Bank were to give any meaningful interpretations to the alternative mechanism, it would have to interpret the concept fundamentally differently from that of the IFC. Foremost, it should not overlook the sovereign nature of the borrowers. It should also recall that the Labor standards applicable to the public and private sectors may not be identical. It may be desirable for those IFIs engaging with both public and private sectors to take a dualistic approach to Labor protection.

\section{The Nature of IFI Labor Standards: Their Relationship to the ILO Standards}

An interesting aspect of the IFI Labor standards is their relationship with the ILO standards. More specifically, when the IFI Labor standards give concrete

70 See "Review and Update of the World Bank's Environmental and Social Safeguard Policies, Phase 3, Feedback Summary: Consultative Meeting with Chinese Governmental Officials" (Beijing 27 October 2015) <http://consultations.worldbank.org/Data/hub/files/ consultation-template/review-and-update-world-bank-safeguard-policies/en/meetings/ final_feedback_summary_for_phase_3_consultation_with_chinese_central_government_ and_institutions_in_beijing_october_27.pdf> assessed 6 May 2018.

71 See "Comments/Observations of the Government of Bangladesh on the World Bank's Environmental and Social Safeguard Framework and other Related Documents" (January 2016) <http://consultations.worldbank.org/Data/hub/files/comments_from_govt_of_ bangladesh_on_essf-01_12_15.pdf> assessed 6 May 2018, pp. 4-5; also "Brief of Statement Made by Mr. Subhash Chandra Garg, Executive Director for Bangladesh, Bhutan, India and Sri Lanka, at the Committee on Development Effectiveness on 24 June and 1 July, 2015 on ESF" <https://consultations.worldbank.org/Data/hub/files/consultation-template/ review-and-update-world-bank-safeguard-policies/en/materials/final_statement_by_ed_ subhash_garg_eds12_on_esf.pdf> assessed 6 May 2018. 
expressions to the core Labor standards, should the reference be made to the ILO fundamental Labor conventions and its Declaration on Fundamental Principles and Rights at Work of 1998, or should the IFI Labor standards simply embody the substance of the core Labor standards without resorting to specific ILO documents?

The practice of IFIs in this regard has been diverse. Those IFIs that adopt a comprehensive scheme of Labor standards tend to make a full reference to the ILO fundamental Labor conventions. This is the case for the IFC's Performance Standards of 2006. The IFC expressly acknowledges that its Labor standards "have been in part guided by a number of international conventions negotiated through the International Labour Organization (ILO) and the United Nations (UN)." A further reference to all eight ILO fundamental Labor conventions was detailed in a footnote. ${ }^{72}$ The same applies more or less to the EBRD's Environmental and Social Policy of 2008, and to the AfDB Group's Integrated Safeguards System of 2013. Some other IF Is with a relevant succinct policy document may avoid explicit reference to the ILO conventions, as in the case of the NIB's Sustainability Guidelines of 2012. Yet, one may also make a brief reference to the ILO Conventions as in the case of the BSTDB's Environmental and Social Policy of 2014. Another way of looking at the matter is by examining the portfolios and activities of the IFIs. Those IFIs engaged more, or exclusively, with the private sector are more inclined to refer to the ILO Conventions. On the contrary, those engaged more with the public sector are more cautious in referring to the ILO Conventions.

To give reference to the ILO standards or not is not just a matter of formality or theoretical interest. Rather, this will largely affect the normative operation of the IFI Labor standards, as well as their foundational authority. Are the IFI Labor standards simply to be understood as no more than a transposed expression of established ILO Labor standards, or rather, does their authority derive from the IFIs themselves and as such constitute a set of Labor standards sui generis? And if there should arise differences of opinions of certain Labor standards, would the IFIs have to resort to the ILO Conventions and relevant jurisprudence to search for a correct interpretation, or would the IFIs be entitled to develop their own institutional standards and jurisprudence?

When the World Bank drafted its Labor standards, a number of Western countries requested the World Bank to link its Labor standards to the ILO

72 IFC, "Performance Standards on Environmental and Social Sustainability" (1 January 2012), Performance Standard 2 Labor and Working Conditions, para. 2. 
Conventions. ${ }^{73}$ The US urged the Bank to incorporate reference to the ILO Declaration on the Fundamental Principles and Rights at Work. ${ }^{74}$ The ILO also actively lobbied for the inclusion of the ILO Conventions. An obvious advantage of reference to the ILO Conventions is that the very content of IFI Labor standards has a reliable source. To borrow the ILO standards could avoid reopening many debates that were already concluded at the time of drafting ILO Conventions. At the end, since the IFIs are not specialized in Labor protection, it may be desirable to heed the knowledge and expertise of the ILO. Moreover, as the ILO standards are internationally recognized standards, it may also be conducive to a uniform application of Labor standards.

Yet, the proposal of incorporating the ILo Conventions in the World Bank social policies was viewed with much vigilance among developing countries. The major concern is that this might amount to a de facto imposition of ILO Conventions and bypass the ratification procedures. ${ }^{75}$ In other words, the ILO fundamental Labor conventions may be enforced through World Bank policies against a borrowing country even if the country has not acceded to all the ILO fundamental Conventions. The traditional ILO approach to the promotion of Labor standards relies upon voluntary ratification of Labor conventions by states. And to ratify a treaty or not is always an essential feature of the sovereign prerogative. However, if the ILO Conventions are referred to in the Labor standards of the IFIs, the sovereign borrowers are obliged to implement those Labor standards in the role of clients irrespective of their non-ratification. World Bank Labor standards would be equivalent to a coerced application of ILO Conventions. It is therefore in this consultation that China suggested the Bank confine itself to reference to general principles, but not the ILO Conventions. ${ }^{76}$

73 See for an example, "Review and Update of the World Bank's Environmental and Social Safeguard Policies, Phase 2, Feedback Summary: Consultative Meeting with Consultation with Government Officials from Belgium and the Netherlands" (Brussels 10 November 2014) <https://consultations.worldbank.org/Data/hub/files/consultationtemplate/review-and-update-world-bank-safeguard-policies/en/meetings/safeguard_ review_phase_2_consultations_2014_-_feedback_summary_brussels_government_and_ multilaterals_meeting_november_10.pdf> assessed 6 May 2018.

74 "United States Comments on World Bank Safeguards Review-Phase 2" (26 March 2015) $<$ https://consultations.worldbank.org/Data/hub/files/2015-3-26_usg_comments_on_ draft_wb_esf_final.pdf $>$ assessed 6 May 2018.

75 For example, the ADB considers the core Labor standards as automatically applicable. "Internationally recognized labor standards, when ratified, are also part of the legislative framework of a DMC. With regard to the Core Labor Standards, no explicit ratification is needed for them to be part of the legislative framework of a country." See ADB, "Social Protection Strategy" (2001).

76 "Review and Update of the World Bank's Environmental and Social Safeguard Policies, Phase 3, Feedback Summary: Consultative Meeting with Chinese Governmental 
Yet, there is another important aspect to the matter. It would not only have normative relevance on operation of the IFI Labor standards, but also has a strong implication for the relationship between the IFIs and the ILO. It is in the interest of the ILO to develop a body of ILO-centered Labor standards at the global level. A reference to the ILO and its work would naturally reinforce the authority of the ILO in Labor matters. To a certain extent, a strengthened role of the ILO is also in the interest of the international community in general. ${ }^{77}$ The emergence of autonomous Labor standards outside the ILO system could possibly divert and compete with the ILO and its standards-setting authority. It is useful to recall an internal observation by an ILO official in 1994 that the ILO faces the challenges of "competing organizations," "competing standards" and ultimately, "competing visions."78

Seen in this light, one may gain a better appreciation of the institutional rivalry between the World Bank and the ILO. The World Bank in its Environmental and Social Framework decided against direct reference to any ILO instruments. ${ }^{79}$ In explaining its decision, the World Bank made it very clear that it is exactly the autonomy of the Labor standards and of the Bank that animates such a political decision. "It is Management's view that the requirement for both World Bank and Borrower to comply with the ES [Environmental and Social] Framework should be self-standing, and should not require reference to external sources to make this judgment." ${ }^{\prime 80}$ The ILO was profoundly

Officials" (Beijing 27 October 2015) <http://consultations.worldbank.org/Data/hub/files/ consultation-template/review-and-update-world-bank-safeguard-policies/en/meetings/ final_feedback_summary_for_phase_3_consultation_with_chinese_central_government_ and_institutions_in_beijing_october_27.pdf> assessed 6 May 2018.

77 For example, the 1996 Ministerial Conference of the wTO in Singapore, as a tentative conclusion to the trade and Labor debate within in the wTo, expressly supports the leading role of ILO as "the competent body to set and deal with" core Labor standards. See WTO, "Singapore Ministerial Declaration" (13 December 1996) <https://www.wto.org/english/ thewto_e/minist_e/ming6_e/wtodec_e.htm > assessed 6 May 2018.

78 Lee Swepston, "The Future of ILO Standards" (1994) 117(9) Monthly Labor Review 16, pp. 16-23.

79 The attitude of the World Bank towards external institutions has been consistently conservative. A known example is World Bank's explicit rejection of the binding force of the resolution of the United Nations (UN) Security Council acting under the Chapter VII of the UN Charter.

8o World Bank, "World Bank Safeguard Policies Review and Update: Summary of Phase 2 Consultations and Bank Management Responses" (July 2015) <https://consultations .worldbank.org/Data/hub/files/consultation-template/review-and-update-world-banksafeguard-policies/en/phases/clean_summary_of_phase_2_consultations_and_bank_ management_reponses_final_draft_for_consultation_july_1_2015.pdf> assessed 6 May 2018. 
disappointed by this. Immediately after the World Bank published its Environmental and Social Framework, the ILO publicly pronounced its dissatisfaction. It stated that "from the outset the ILo expressed concern with Bank Management's decision to exclude direct references to ILO core Labor conventions from the ESF [Environmental and Social Framework]." ${ }^{\prime 1}$

The case of the World Bank makes a good example that highlights the autonomous status of the IFI Labor standards. The legal validity of such Labor standards does not depend on the ILO Conventions or other normative documents. Nor is the substance of the Labor standards defined or constrained by the ILO conventions. The IFI Labor standards constitute a set of independent, self-contained Labor standards with distinct sources, procedures and mechanisms, in parallel to traditional concept of international Labor law centered on and formulated by the ILO. These Labor standards do strengthen the Labor protection at global and transnational levels, but they are beyond the terrain of ILO standards. In this sense, even though the substance of the IFI Labor standards might be identical to those in the ILO standards, they are capable of supplementing, or even competing with, the ILO standards. They are not at all simply a repetition of existing standards.

The difference between the World Bank and the ILO is not concerned with actual Labor standards, but about who is entitled to prescribe Labor protection in an increasingly globalized world. While the authority of the ILO is highly acknowledged, the World Bank has refused to concede the ILO a monopolized say on Labor standards. Putting it differently, the ILO does not have higher authority than the World Bank in speaking to Labor standards. It can be expected that close cooperation between the World Bank and the ILO will increase and grow steadily in the future. Meanwhile, with assistance from the ILO, the World Bank is likely to develop its own expertise and knowledge in Labor protection in connection with its own Labor policy and project implementation.

\section{Philosophical: Tension between a Neoliberal Perspective and a Rights-based Approach}

The foremost challenge for IFIs to incorporate Labor standards is not only institutional, but also intellectual and philosophical. The most difficult part is

81 ILO, "Statement on the World Bank Environmental and Social Policy" (8 August 2016) <http://www.ilo.org/global/about-the-ilo/newsroom/statements-and-speeches/ WCMS_508328/lang--en/index.htm> assessed 6 May 2018. 
how to integrate Labor protection into the mainstream economic theories of IFIs. Typically, an economic perspective treats Labor as a factor of production and is usually in favour of flexibility of Labor markets and deregulation of social protection.

The controversies surrounding the World Bank publication "Doing Business" is an illustrative example of the embedded neoliberal economic thoughts of the IFIs. ${ }^{82}$ "Doing Business" is a flagship publication of the World Bank launched in 2004, aiming to measure the business environment across the world with quantitative indicators. In its early years, the "Employing Workers" indicator largely measured rigidity of hiring and firing workers and their employment conditions. Its underpinning philosophy is that rigid Labor regulation leads to unemployment in formal sectors, and ultimately reduction in productivity growth. ${ }^{83}$ Accordingly, the more regulatory and protective a country's Labor regulations are, the lower ranking it receives. ${ }^{84}$ And the recommended reform measures include, among others, introduction of part-time and fixed-term employment contracts, and reduction of the minimum wage for young workers. ${ }^{85}$

This provoked fierce protests from the ILO, trade unions and Labor law scholars in general. ${ }^{86}$ The ILO criticized the methodological flaws of the Employing Workers indicators and expressed the concern that the ranking system would "discourage countries from ratifying and abiding by international Labor Conventions and Recommendations." ${ }^{87}$ The international trade unions are profoundly concerned with the fundamentally bias against Labor regulation of the Employing Workers indicators. They condemned in particular the fact that the World Bank, in using the indicators, was eliminating workers' protection. ${ }^{88}$ In response, the World Bank conceded a more balanced approach to Labor protection, committed to a better alignment with the ILO core Labor

$82 \quad$ For the ongoing controversy regarding the publication, see Hannah Murphy, "The World Bank and Core Labor Standards: Between Flexibility and Regulation” (2014) 21 Review of International Political Economy 399.

83 See World Bank, "Doing Business in 2004," p. 29.

84 On the politics of knowledge behind the ranking and a case study of the Doing Business Indicators, see Kevin E. Davis, Benedict Kingsbury \& Sally Engle Merry, "Indicators as a Technology of Global Governance," (2012) 46 Law and Society Review 71, pp. 71-104.

85 See World Bank, "Doing Business in 2004," p. 30.

86 See Yaraslau Kryvoi, "The World Bank and the ILO: Two Visions of Employment Regulation" in Roger Blanpain \& Claire Grant (eds), Fixed-term Employment Contracts: A Comparative Study (Wolters Kluwer 2009), pp. 47-59.

87 See International Labor Office, "The United Nations and Reform: Developments in the Multilateral System, World Bank Doing Business Report: The Employing Workers Indicator" (November 2007) GB.300/4/1.

88 ITUC/Global Unions, “The IFIs' Use of Doing Business to Eliminate Workers' Protection: Analysis of Doing Business 2008 and New Country Evidence" (Washington 2007) $<$ https:// www.ituc-csi.org/IMG/pdf/doing_business.pdf> assessed 6 May 2018. 
standards, ${ }^{89}$ and subsequently broadened the spectrum of measurement to include protective elements such as job quality. As of 2011, "Doing Business" has removed Labor regulation from the measuring criteria of ranking. Instead Labor regulation is included in the publication only as a referential annex.

The difference between a neoliberal approach and a rights-based approach is indeed structural. Another telling example is the attitude of the IFIs towards trade unions. The trade unions are considered to be free riders in the view of the World Bank. ${ }^{90}$ The International Monetary Fund is reported to hold the same opinion. ${ }^{91}$ In essence, trade unions are difficult to analyze in economic terms of efficiency and productivity. In the 2017 evaluation of the IMF on its social policy, the IMF staff was reported to have felt that the IMF and ILO staffs "did not speak the same language." 92

To fully integrate Labor protection in the work of IFIs would require a paradigmatic change in economic thinking to reconceptualize Labor as an inherent good. Labor is approached not as purely a factor of production in economic terms, but also as one of the very foundational values upon which economic activities are based. In other words, the IFIs have to embed Labor protection into their economic work as an essential part of their foundational philosophy, i.e., what are the elements of a sound economy and where the boundary of economic activities lies. ${ }^{93}$ This practically would mean to modify or even rewrite the philosophy of the mainstream economic theory, which is a formidable task.

\subsection{Constitutional: The Contestable Intra Vires Basis}

The intervention of IF Is in Labor regulation calls for the question of constitutionality of their policies. Policies and actions of IF Is, especially those to which member states have a strong stake, have to be grounded solidly on an intra

89 See World Bank, "Doing Business 2010," pp. 22-23; World Bank, "Doing Business 2011," p. 94.

9o See Hannah Murphy, "The World Bank and Core Labor Standards: Between Flexibility and Regulation" (2014) 21 Review of International Political Economy 399, p. 405, p. 417.

91 See Franz Christian Ebert, "International Financial Institutions' Approaches to Labor Law: The Case of the International Monetary Fund," in Adelle Blackett \& Anne Trebilcock (eds), Research Handbook on Transnational Labor Law (Edward Elgar 2015), pp. 124-137.

92 IMF, "The IMF and Social Protection: 2017 Evaluation Report," p. 30.

93 For example, the integration of environmental protection in the policy of the World Bank is greatly facilitated by the publication of "Development and the Environment" in 1992, which "presented environmental issues in a language that economists (inside and outside the Bank) could understand." See Robert Wade, "Greening the Bank: The Struggle over the Environment, 1970-1995" in Devesh Kapur, John P. Levis \& Richard Webb (eds), The World Bank: Its First Half Century, Volume 2: Perspectives (Brookings Institution Press 1997), pp. 712-713. 
vires basis, enumerated or implied, from the constitutional documents of IFIs. Otherwise, ultra vires acts of an international organization may be politically challenged by dissenting member states, but may also incur institutional responsibility under international law. ${ }^{94}$

Most constitutions of IFIs do not expressly provide for constitutional mandates for engagement with Labor issues or environmental and social policies in general. With few exceptions, ${ }^{95}$ IFIs are often charged with a seemingly neutral, purely financial role. An expansive interpretation of their mandate would still stop short of direct engagement on Labor policy. A good example to the point can be seen from information revealed in the 2017 evaluation of the IMF on its social policy. According to the report, the initiative of social protection was skeptically received among IMF staff and its relevance to the mandate of the IMF was questioned..$^{96}$ Similarly, internal skepticism also arose when the World Bank first introduced its environmental policy in 1970s. ${ }^{97}$

Moreover, many IFIs have a non-intervention clause in their constitutions. For example, the World Bank is required not to consider "political or other non-economic influences or considerations" in its decision-making. ${ }^{98}$ In the same vein, the IFC is prohibited from interfering in the political affairs of any member, and can only weigh economic considerations in their operations. ${ }^{99}$ The same principle applies almost identically also to ADB and AIIB. ${ }^{100}$ The principle of non-intervention is particularly relevant in the case of Labor regulation, a matter so deeply considered as domestic. And any intervention by IFIs would require compelling justifications and solid constitutional grounds.

Consequently, IFIs have developed their social policies in a very pragmatic manner. The engagement of IFIs with Labor protection is built around the

94 See "Draft Articles on the Responsibility of International Organizations, with Commentary," in United Nations International Law Commission Report on Work of Its Sixty-third Session (26 April to 3 June and 4 July to 12 August 2011) UN Doc. A/66/10, pp.54-172.

95 Among others, the EBRD is a known exception for its mandate to "foster the transition towards open market-oriented economies and to promote private and entrepreneurial initiative in the Central and Eastern European countries." See Agreement Establishing the European Bank for Reconstruction and Development art 1.

96 IMF, “The IMF and Social Protection: 2017 Evaluation Report," p. 30.

97 See Robert Wade, "Greening the Bank: The Struggle over the Environment, 1970-1995" in Devesh Kapur, John P. Levis \& Richard Webb (eds), The World Bank: Its First Half Century, Volume 2: Perspectives (Brookings Institution Press 1997), pp. 626-627.

98 Articles of Agreement of the International Bank for Reconstruction and Development art 3.05(b).

99 Articles of Agreement of the International Financial Corporation art 3.9.

100 Articles of Agreement of the Asian Development Bank art 36(2); Articles of Agreement of the Asian Infrastructure Investment Bank art 31(2). 
concept of sustainability. ${ }^{101}$ In some cases, this has been done without an enumerated constitutional basis-environmental and social sustainability is considered an implied element to the notion of sound economy. The IFC justifies its environmental and social policy based upon the linkage between a sustainable private sector development and poverty reduction. ${ }^{102}$ The World Bank emphasizes the relevance of social development and inclusion to the World Bank Group's corporate goals of ending extreme poverty and promoting shared prosperity, and further justifies its engagement in light of its support to the realization of human rights. On the contrary, the AIIB is fortunate to be equipped with an enumerated competence to make bank policies to address environmental and social dimensions. ${ }^{103}$ The EBRD tries to anchor its social policies on the constitutional commitment to promote "environmentally sound and sustainable development."104 Егв highlights its nature of being a funding institution of European Union and seeks to align its environmental and social policy with those of the European Union. ${ }^{105} \mathrm{~A}$ general observation is that, with few exceptions, the constitutional ground for IF Is to engage in Labor policy remains weak and contestable.

Therefore, the IFIs' Labor regulation started with technical and morally uncontested fields, typically, safe working conditions and prohibition of use of forced Labor. The IFI Labor standards quickly expanded to an extensive list. The environmental and social policy is usually built upon the so-called "do no harm" approach. Such a "do no harm" approach was expressly acknowledged by the IFC in 2006 when explaining the very purpose of its environmental and social policy. ${ }^{106}$ The raison d'être is to prevent and remedy the undesirable external effects of international financing. This presents the image of IFIs' social

101 One also observes that, with the introduction of Labor policy, IF Is started to rename their instruments of safeguards policy to be sustainability policy, or environmental and social policy, indicative of a paradigmatic shift of approaches. For an excellent exposition on the topic in the context of the IFC, see Christopher Wright, "From 'Safeguards' to 'Sustainability': The Evolution of Environmental Discourse inside the International Financial Corporation" in Diane Stone \& Christopher Wright, The World Bank and Governance: A Decade of Reform and Reaction (Routledge 2007), pp. 67-87.

102 IFC, "Policy on Social \& Environmental Sustainability" (30 April 2006), p. 1.

103 "The Bank shall ensure that each of its operations complies with the Bank's operational and financial policies, including without limitation, policies addressing environmental and social impacts." Articles of Agreement of the Asian Infrastructure Investment Bank, art 13(4).

104 Agreement Establishing the European Bank for Reconstruction and Development, art 2.1 (vii).

105 EIB, "Environmental and Social Policy" (2009), p. 5.

106 IFC, "Policy on Social \& Environmental Sustainability" (30 April 2006), p. 2. 
policies as an unavoidable necessity. Ten years later, however, the World Bank pronounced a more ambitious position and vowed to "go beyond" the "do no harm" approach. While it remains unclear what this means in practice, one may reasonably speculate that the World Bank could be more dedicated to intrusive social policies. This bold assertion might bring the constitutionality, as well as the legitimacy, of Labor and other social policies back to the forefront of debate.

\subsection{Institutional: Building Knowledge and Capacity}

Even if it seems fashionable for IFIs to commit to Labor standards, to actualize and realize them in specific projects remains a formidable task for IFIs. Global governance is largely about governance through expertise and knowledge. ${ }^{107}$ IFIs are also in urgent need to accumulate knowledge about Labor regulation in assessing project risks and also in monitoring project implementation on site. The World Bank in its Social Protection and Labor (SPL) Strategy 2012-22 "highlights the central importance of appropriate knowledge in SPL practice, especially through engendering a global South-South conversation about what works and how in SPL."108

IFIs have been increasing their investment in acquiring expertise and knowledge about Labor. For example, it was reported that in 2005 the EBRD "ran a series of training workshops on Labor issues" with 125 attendants at the bank's headquarters. ${ }^{109}$ And in 2007 the EBRD organized a two-day training course on Labor issue for its whole staff of the Environment and Sustainability Department. ${ }^{110}$ The World Bank also started to recruit Labor experts to assist its work in Labor protection. A separate Labor department was set up as well. Inter-agency collaboration between IFIs and the ILO could be expected to intensify in the forthcoming years.

The incorporation of Labor protection is in a way reshaping and reconstituting the IFIs, intellectually and institutionally. Ultimately, if IFIs seriously uphold environmental and social sustainability as their core values, this may even contribute to a quiet change of the institutional culture within IFIs.

107 For an interesting study on the World Bank's environmental policy from a knowledge/ power perspective, see Michael Goldman, Imperial Nature: The World Bank and Struggles for Social Justice in the Age of Globalization (Yale University Press 2005).

108 World Bank, "Social Protection and Labor Strategy 2012-22: Resilience, Equity, and Opportunity" <http://siteresources.worldbank.org/SOCIALPROTECTION/Resources/ 280558-1274453001167/7089867-1279223745454/7253917-1291314603217/SPL_Strategy _ 2012-22_FINAL.pdf > assessed 6 May 2018, p. 11.

109 See ebrD, “Sustainability Report 2005," p. 18.

110 See EBRD, "Sustainability Report 2007," p. 47. 


\subsection{Operational: Division between Public and Private Sectors}

Difference between public and private sectors remains an important factor that is underappreciated in the formulation and implementation of Labor standards. Sovereign states and private corporations are fundamentally different in term of legal nature, capabilities, influences, resources and available measures. To require a private company to implement IFI Labor standards is usually no more than asking the private company to abide by national laws. It is in most cases "a law-abiding requirement." On the contrary, to require sovereign states to abide by IFI Labor standards may amount to imposition of a set of international Labor standards on states, in essence "a law-changing requirement."

Although the World Bank policy requirement strictly speaking is projectspecific, the implementation of relevant Labor standards may also have broad implications for domestic Labor standards in general. It is observed by David Freestone, a former chief counsel and the head of Environment and International Law Group at the World Bank, that in the fields of environmental and social policies, "many borrowing countries have internalized the broad principles of these procedures and incorporated them into national law."111 In other words, in the case of sovereign loans, the enforcement of IFI Labor standards may compel legal reform and policy change of a sovereign state.

There is a real risk for a sovereign state to take, i.e., to acquire a loan would have to be traded for higher Labor standards. It could be a burden both for the borrowing countries and for the lending institutions. It is natural that IF Is engaging with the public sector experience much resistance from their borrowers. Many IFIs have been very cautious on the issue whether and how far the Labor standards should be prescribed.

It might be desirable for those IFIs working with both public and private sectors to apply different standards to different kinds of clients. Noticeably, the AIIB has adopted a dualistic approach to Labor standards. In addition to those general standards, the AIIB sets a specific provision addressing the "labor management relationships in private sector projects." The private projects are requested to develop a sound Labor management system consistent with national law including timely payment, adequate rest, fair treatment and non-discrimination, compliance with national law relating to workers' organizations and collective bargaining, and an accessible grievance mechanism. ${ }^{112}$ The practice of the AIIB serves as a good example of how a dualistic approach can function.

\footnotetext{
111 David Freestone, The World Bank and Sustainable Development: Legal Essays (Martinus Nijhoff Publishers 2013), p. 49.

112 АІІв, "Environmental and Social Framework" (2016), p. 36.
} 
The issue of Labor protection has become a prominent social and political issue in a globalized era. Labor protection is no longer monopolized by sovereign states within their territory. Increasingly Labor standards are addressed in a transnational context. The engagement of the IFIs in Labor protection is a visible example. Labor standards are recognized and enforced in policy documents of IFIs. In the globalization era, Labor issues have become such a pertinent and universal issue that they permeate various sections of international politics. Labor protection becomes a language of empowerment capable of generating legitimacy for action. This makes it possible for international actors to participate in global Labor governance, directly or indirectly, proactively or responsively.

As IFIs increasingly turn from a fiscal perspective on development to a governance approach to development, IFIs are moving away from their purely financial nature. Instead, by focusing on environmental protection and social justice, IFIs are turning into actors of public authority that are capable of enacting and enforcing their own institutional values, principles and standards. Increased engagement with Labor protection and other social policy is transforming the institutional nature of those IFIs into public authorities of global governance.

When IFIs set and enforce Labor standards vis-à-vis their clients, be they sovereigns or private entities, IFIs recognizably entertain a considerable degree of power and influence. These Labor standards are implemented against all clients indiscriminately on a project-specific basis, yet capable of general influences and constraints on the preferences and decisions of clients. Of course, one may say that states and companies are free to decide whether to take loans from IFIs or not. Yet loans from IFIs in the modern world are extremely scarce resources, and access to IFI loans in most cases is a privilege. This is particularly true for development loans and grants from IFIs. Once a loan agreement is concluded, the borrowers are obliged to implement the Labor standards of IFIs in the financed projects. In a way, financial loans are powerful instruments of leverage for IFIs to globalize Labor standards.

The notion of public authority here is defined in a functionalistic logic. ${ }^{113} \mathrm{As}$ long as an institution engages in defining public interest and providing public good in the political dimension of a society, irrespective of whether the

113 For a useful discussion on what is the political, see Chris Thornhill, "Public Law and the Emergence of the Political" in Cormac Mac Amhlaigh (et. al), After Public Law (Oxford University Press 2013), pp. 25-55. 
authority is based upon a legal mandate in its constituent document, the institution may be understood to be exercising public authority. The public authority of IFIS derives from the very fact that the IFIs are dealing with public matters in international society. As globalization deepens, environment, indigenous people, Labor, and other social issues increasingly transcend national borders and become global concerns. Authorities are continuously generated by the actual regulatory exercise over these public matters. ${ }^{114}$

This approach to public authority is different from a formalistic approach to ascertaining the public nature of an institution. According to the prevalent opinion, ${ }^{115}$ the publicness of IFIs can be traced back to the legal foundations of their establishment. If an international organization is established at intergovernmental level, then its contribution to public goods and its public nature is presumed. Global regulatory institutions are often treated as "public entities" perse. ${ }^{116}$ The delegation of powers from states confers an original legitimacy to IFIs. Yet, an intergovernmental organization could also be perfectly a private institution among the constituent parties. One may think of the International Tin Council that bankrupted in London and raised a series of law suits against it. ${ }^{117}$ The nature of an international organization being public or private very much depends on what it does and in whose interests it acts. As long as it is capable of, and is actually embarking upon, the creation and regulation of public goods, an international institution exercises public authority.

IFIs' involvement in regulating social issues can be seen in light of institutional evolution, as most of those matters are not expressly enumerated as their institutional mandates. The regulatory authority often comes as implied powers and relies on innovative interpretations of the constituent documents. This brings doubt as to the constitutionality of IFIs' engagement in Labor and social policies. However, such constitutional weakness in reality is often compensated by functional effectiveness of the institution, by the acquiescence of

114 It is similarly observed by a scholar of public law in the domestic context that "all governing bodies now claim their authority not from some original conferral of jurisdiction but from their ability effectively to discharge public (i.e., social) tasks." Martin Loughlin, Foundations of Public Law (Oxford University Press 2010), p. 462.

115 Some tend to take a formalistic approach by looking at the legal basis of an institution. See Armin von Bogdandy, Philipp Dann \& Matthias Goldmann, "Developing the Publicness of Public International Law: Towards a Legal Framework for Global Governance Activities" (2008) 9 German Law Journal 1375, pp. 1383-1384.

116 See Benedict Kingsbury, "International Law as Inter-Public Law" in Henry R. Richardson \& Melissa S. Williams (eds), Nomos XLIX: Moral Universalism and Pluralism (New York University Press 2009), p. 169.

117 See Maclaine Watson \& Co. Ltd v International Tin Council [1989], 26 October 1989, United Kingdom House of Lords, 81 International Law Reports 670. 
the regulated and of international society at large, and, at times, by the support of dominant actors within the institution.

The characterization of IFIs as public authorities carries with it four noticeable implications. First of all, the IFIs, when exercising public authority, are to be bound by a set of principles of public laws, both procedural and substantive. The principles such as reasoned decisions, public participation, transparency, rationality, proportionality are all relevant. ${ }^{118}$ And as such, these principles are to be found beyond the constituent documents of an international institution. They might have to be drawn from general principles of law or from comparative citations to domestic public laws. ${ }^{119}$ Secondly, accountability regimes are to be developed for IFIs in relation to their exercise of public authority. Such accountability regimes would grant access to wronged individuals to challenge the activities of IFIs in Labor and social policy. Of course, such accountability regimes could be more diverse than those in domestic arenas. Institutional arrangements such as Ombudsman, or the Inspection Panel in case of the World Bank, are good examples. Thirdly, the changing self-perception of IFIs may bring a conscious adaptation of institutional culture, language, structure, and style of how power is exercised, as well as perceived institutional legitimacy, ${ }^{120}$ further accelerating an institutional transformation into public authorities. Increasingly, the IFIs absorb social justice as their institutional values and rationales. Last of all, but not least in implications, IFIs can construct and expand public spheres for debating and deliberating public goods at the global level. Through engaging Labor and other social policies, IFIs will thereby contribute to the developing and shaping of a global public.

118 See Benedict Kingsbury, Nico Krisch \& Richard B. Stewart, "The Emergence of Global Administrative Law" (2005) 68 Law and Contemporary Problems 15.

119 See Armin von Bogdandy, "General Principles of International Public Authority: Sketching a Research Field" (2008) 9 German Law Journal 1909.

120 For a useful examination of the remodeling effect the environmental policy had on the IFC, see Christopher Wright, “From 'Safeguards' to 'Sustainability': The Evolution of Environmental Discourse inside the International Financial Corporation" in Diane Stone \& Christopher Wright, The World Bank and Governance: A Decade of Reform and Reaction (Routledge 2007), pp. 67-87. 